\title{
The potential opportunities and limitations of Public Engagement in Science and Technology ${ }^{1}$ Potenciais e limites do Engajamento Público em Ciência e Tecnologia
}

\author{
Aline Bastos \\ Postgraduated Visiting Researcher at University of the West of England (UWE) in Bristol, UK. PhD Student in Communications \\ at Federal University of Minas Gerais, Brazil. E-mail: aline.bastos@gmail.com \\ Márcio Simeone Henriques \\ Professor at Communications Department at Federal University of Minas Gerais, Brazil. E-mail: simeone@ufmg.br \\ Clare Wilkinson \\ Associate Professor at the Science Communication Unit, UWE Bristol, UK. E-mail: clare.wilkinson@uwe.ac.uk
}

\begin{abstract}
:
Rather than taking an instrumental communications approach in which the public is seen as a passive vessel in which scientific information can be deposited in order to be "literate" in science; the focus has shifted to an approach favour a dialogic and relational view of communication based on public engagement. On the other hand, public engagement can lead to a questioning of science itself as a social institution with public communication and engagement continuing to play a role in how science itself is able to control its symbolic power. This article examines recent trends towards public engagement in Science and Technology (S\&T), limitations of such approaches and their potential for strengthening democracy and citizenship where science and technology is concerned.
\end{abstract}

\section{Keywords:}

Science Communication; Public Engagement; Citizenship.

\begin{abstract}
Resumo:
Em vez de adotar uma abordagem de comunicação instrumental, em que o público é visto como um recipiente passivo da informação científica e que precisa ser "alfabetizado" em ciência; o foco mudou para uma abordagem que favorece uma visão dialógica e relacional da comunicação, baseada no engajamento público. Por outro lado, o engajamento público pode levar a um questionamento da própria ciência como uma instituição social, com a comunicação pública e o engajamento público a desempenhar um papel na forma como a própria ciência é capaz de controlar seu poder simbólico. Este artigo examina as tendências recentes em relação ao engajamento público em Ciência e Tecnologia ( $\mathrm{C} \& \mathrm{~T}$ ), as limitações de tais abordagens e seu potencial para fortalecer a democracia e a cidadania no que diz respeito à ciência $\mathrm{e}$ tecnologia.
\end{abstract}

\footnotetext{
${ }^{1}$ A previous version of this paper was presented at the 2017 Conference of the International Association for Media and Communication Research (IAMCR) in Cartagena, Colombia.
}

INTERIN, v. 24, n. 2, jul./dez. 2019. ISSN: 1980-5276. 
Palavras-chave:

Comunicação de Ciência; Engajamento Público, Cidadania.

\section{Introduction}

Since the seventeenth century, Western societies have considered science to be the dominant source of knowledge in society. Since then, scientific knowledge has been identified as "the officially privileged form of knowledge and its importance for the life in contemporary societies does not offer contestation" (SANTOS, 2006, p.17). Nowadays, science is a standard of knowledge, a voice of authority and truth, that potentially could be seen as excluding any other form of knowledge and understanding that is not considered scientific: "It is, of course, a tautology, but a tautology that has been established as a power structure" (SANTOS, 2006, p.705).

This notion of science corroborates the concept of field and scientific capital, developed by the French sociologist Pierre Bourdieu, which indicates the relations of power and recognition among scientists as an autonomous group. This symbolic power allows an individual or institution to intervene in the course of events in order to influence actions and beliefs of others, by producing and transmitting symbolic forms in the public space. In such a setting science, as an institution and body of work, would seek to carefully communicate and maintain its symbolic power. However, even Foucault points to the possibility of social relations transformation by organized actions amongst social groups: "(...) we are never imprisoned by the power, we can always modify its domination in determined conditions according to a precise strategy" (FOUCAULT, 1977, p.65).

In this context, the development of science communication in several countries could be identified as the process of science informing a perceived lack of public knowledge about science and technology, filling that gap in knowledge under the guise of "scientific literacy". Understanding of science would be conveyed in a one directional manner, akin to a "pill" which encapsulates scientific knowledge to an audience that would then passively access it. This approach to scientific dissemination has become known as the deficit model (LEWENSTEIN, 2010). 
However more latterly, criticisms of this model have given rise to the contextual model. Though this has similarities to scientific literacy, it recognizes that science communication takes place in a social context. It considers demographic characteristics, social configurations, trust in institutions, and other factors that can shape public knowledge of science and technology. Yet some may still see the contextual model as having a tendency to remain focused on providing information, which may not address the underlying causes of the need for improved scientific engagement or enable public participation (LEWENSTEIN, 2010).

This article examines recent trends towards public engagement in Science and Technology (S\&T), limitations of such approaches and their potential for strengthening democracy and citizenship where science and technology is concerned. Finally, it will consider how shifts to public engagement in science and technology reflect a change in sciences symbolic power.

\section{Public Engagement in Science and Technology: Contexts}

Massimiano Bucchi (2008) points out that one of the characteristics of contemporary science is its intrinsic fragmentation and heterogeneity. In this sense, changing trends in science communication may also reflect an increased awareness of the multifaceted nature of citizens, including the increasing diversity of scientific issues which may have relevance to them and demand greater involvement. Thus, communicative practices with a dialogic, interactive and participatory focus have tended to become more accepted than those focused only on transmission. Rather than taking an instrumental communications approach in which the public is seen as a passive vessel in which scientific information can be deposited in order to be "literate" in science; the focus has shifted to an approach which values lay knowledge with public engagement in science and technology, representing alternatives that favour a dialogic and relational view of communication (BASTOS, 2016).

Lewenstein (2010) pinpoints the 1990s as the era when discussion about social appropriation of knowledge, in the context of the sciences began recognizing that in some circumstances local knowledge, such as that gleaned by publics and citizens, should be given more authority and address a potential transfer of power to non-

INTERIN, v. 24, n. 2, jul./dez. 2019. ISSN: 1980-5276. 
scientists. The idea of valuing local knowledge emerged particularly in settings where communities have built up sources of reliable and collective knowledge developed over many years, contexts such as patient awareness or working knowledge. This knowledge was often actively built by the community as it carries information drawn from many sources to solve their problems. In this sense we may identify actions amongst social groups who sought to transform their relations with science as a body of knowledge (EPSTEIN, 2000).

Citizen science programs work in a way which seeks to encapsulate such 'local' knowledge to help scientists, albeit that in some cases citizens will not already be mobilizing. In some citizen science programs, audiences are simply data collectors for scientists; but there are many others where participants themselves help to define the scientific issues under study and have full access to data collected by volunteers from all over the country or even the world. It has been said that there are three types of citizen science projects: contributory, collaborative and co-created (BONNEY ET AL, 2009). Contributory projects are usually planned by scientists with contributions by non-scientists only in the form of data collection. Collaborative projects are also developed by scientists but here there are contributions by publics who can refine the project, analyze the data and help to disseminate the findings. Finally, co-creation projects are designed by scientists and non-scientists together, and at least some members of the public are actively involved in all steps of the scientific process.

It is important to note that the evolution of digital tools has contributed to the considerable expansion of citizen science projects over recent years, facilitating increased public participation. Digital platforms and mobile technologies have been increasingly used by scientists to allow participants to collect and submit data to researchers. Hence the term e-Citizen Science (ECC) or "cyberscience" is set as a new scientific approach to use technological platforms of communication and information management to increase the involvement of non-scientists in science and technology processes. Information and communication technologies have therefore created opportunities not only for increased sharing of information about science and technology, for instance via blogs, social media sites and Twitter, but have also increased the ways in which members of the public and citizens might contribute their

INTERIN, v. 24, n. 2, jul./dez. 2019. ISSN: 1980-5276. 
own ideas and opinions through such technologies (LEADBEATHER, 2008). This extends the boundaries of science as a symbolic form to not only share its knowledge with publics, but to bring them within its techniques and forms.

Similarly, public engagement policies in science and technology have developed a path towards citizen participation which seeks to bring citizens more actively into the decision-making process on scientific issues. Stakeholders and political decision-makers have traditionally interacted to deliberate on science and technology issues. It is all about listening to others opinions, knowledge and values, developing shared understandings, collaborating and being open to change points of view. These practices have extended to include more widely public participation, in the form of opportunities like citizens' juries, consensus conference and science festivals, encouraging public debates and participation (WILKINSON \& WEITKAMP, 2016). Such techniques seek to broaden the publics' role in sciencerelated issues, giving citizens a more active role, alongside scientists and other actors involved in the process in order to generate solutions to some of the many social demands from science.

The 'Public Engagement for Innovation 2020 project' funded by the European Union has established a conceptual and empirical framework for public engagement, seeking to identify, analyze and refine innovative actions and governance instruments in various countries (RASK ET AL, 2016). Data from the latest report which examined over fifty cases of public engagement from thirty seven countries, indicates that public engagement practice is increasingly expanding in the world with public policies, initiatives by civil society organizations and research at universities. It identified a tendency for institutionalization and a gradual formalization of public engagement within such institutional structures. Strong involvement and growth of the 'fourth sector' was also identified, involving a network of hybrid and voluntary publics, similar to the public education advocated by Dewey (2004). "This type of action is often labeled by the literature as 'direct involvement of citizens' that distances itself from the 'involvement of stakeholders or stakeholders'" (RASK ET AL, 2016, p. 6) and therefore is far more fluid in its mobilisation.

From the empirical analysis of the cases gathered in this same report, five possible categories of public engagement were established: public information, public 
activism, public consultation, public deliberation, public participation (RASK ET AL, 2016). The dissemination of information is not considered to be the most effective, but remains the basis for public engagement. Public information aims to inform or educate citizens, including using online communication platforms, social networks and mobile applications. The flow of information is one-way, but mechanisms exist to deal with public feedback, such as public hearings, public meetings and awareness-raising activities. The actions of public activism propose to inform decision makers and generate a conscience, in order to influence the processes of decision making. The flow of information is also one-way, but in the sense of citizens to decision makers, at the initiative of the public itself. These are actions that are emotionally interconnected with individuals, in which ethical and moral emotions and values provoke a sense of urgency, triggered by manifestations and protests, for example. Already public consultation intends only to take the opinions of the public on certain topics, yet no formal dialogue is implemented. And in public deliberation, the objective is to facilitate discussion and deliberation on science and technology issues, where the outcome can affect decision making. Here information is exchanged between decisionmakers and the public, dialogue is facilitated and information flow is bidirectional as in consensus conferences and citizens' deliberative juries, for example. And, finally, public participation intends to give citizens full or partial power over political issues. The flow of information is a two-way communication with co-governance and direct democracy mechanisms as a participatory budget.

The advance of these public engagement practices internationally contains an undeniable link to what Steve Miller calls the "Three-D Triangle" - dialogue, discussion and debate - as the basis for much of today's professional practice and production in the communication of science. Currently, as the Argentine researcher Carina Cortassa says:

\footnotetext{
Attention to the ways in which communication between scientists and publics is established has more than surpassed the interest, knowledge and attitudes triad that has remained for decades, not only in academic research, but also in the context of public policies on scientific culture (CORTASSA, 2012, p.39).
}

Public engagement has therefore become an increasingly adopted model, by the scientific community, its policy surroundings, and amongst both provoked and

INTERIN, v. 24, n. 2, jul./dez. 2019. ISSN: 1980-5276. 
emerging public and citizen groups, however next it is important to consider how and whether public engagement is truly influencing science at a symbolic and institutional level.

\section{Public engagement in S\&T towards an institutionalization}

Public engagement is usually defined by scientists themselves, who approach and reach a broader and non-specialized audience (BAUER \& JENSEN, 2010; BULTITUDE, 2011; WILKINSON \& WEITKAMP, 2016). From the scientific researchers perspective it may then include a wide range of activities such as lectures in public or in schools, interviews with journalists for newspapers, radio or television, articles on science for newspapers or magazines, participation in debates, and "scientific cafes", amongst others.

Beyond the individual scientist, various governmental and non-governmental institutions have also been stimulating public engagement practice in Europe. For instance, the European Union, the House of Lords and the National Co-ordinating Center for Public Engagement (NCCPE) have all promoted agendas which are encouraging of public engagement to anticipate, or overcome any crisis of confidence that might arise in society relating to science (BULTITUDE, 2011). Whilst, funding organizations such as as Wellcome Trust in the United Kingdom have been expanding efforts to evaluate the impacts of their public engagement efforts, including how to support researchers and public engagers as well as 'what works' in techniques such as co-production ${ }^{2}$.

Over the years, universities' funding and ranking - as well as new procedures and funding guidelines for scientific research - have testified a growing institutional pressure for scientists to commit to public engagement. To support this governance, RCUK an umbrella organization for various Research Councils in the United Kingdom supported a model for understanding the different effects of public engagement. The

\footnotetext{
${ }^{2}$ Available from: https://wellcome.ac.uk/news/how-were-using-research-and-evidence-makesure-public-engagement-has-big-impact
}

INTERIN, v. 24, n. 2, jul./dez. 2019. ISSN: 1980-5276. 
triangle of public engagement shows three overlapping effects called "transmitting," "collaborating," and "receiving," without a hierarchy: all of which are useful and equally valid. Any science communication activity is likely to involve a mix of these three approaches, according to the needs of the public and the scientists involved.

Fig. 1 - Public Engagement Triangle from Science for All (2010)

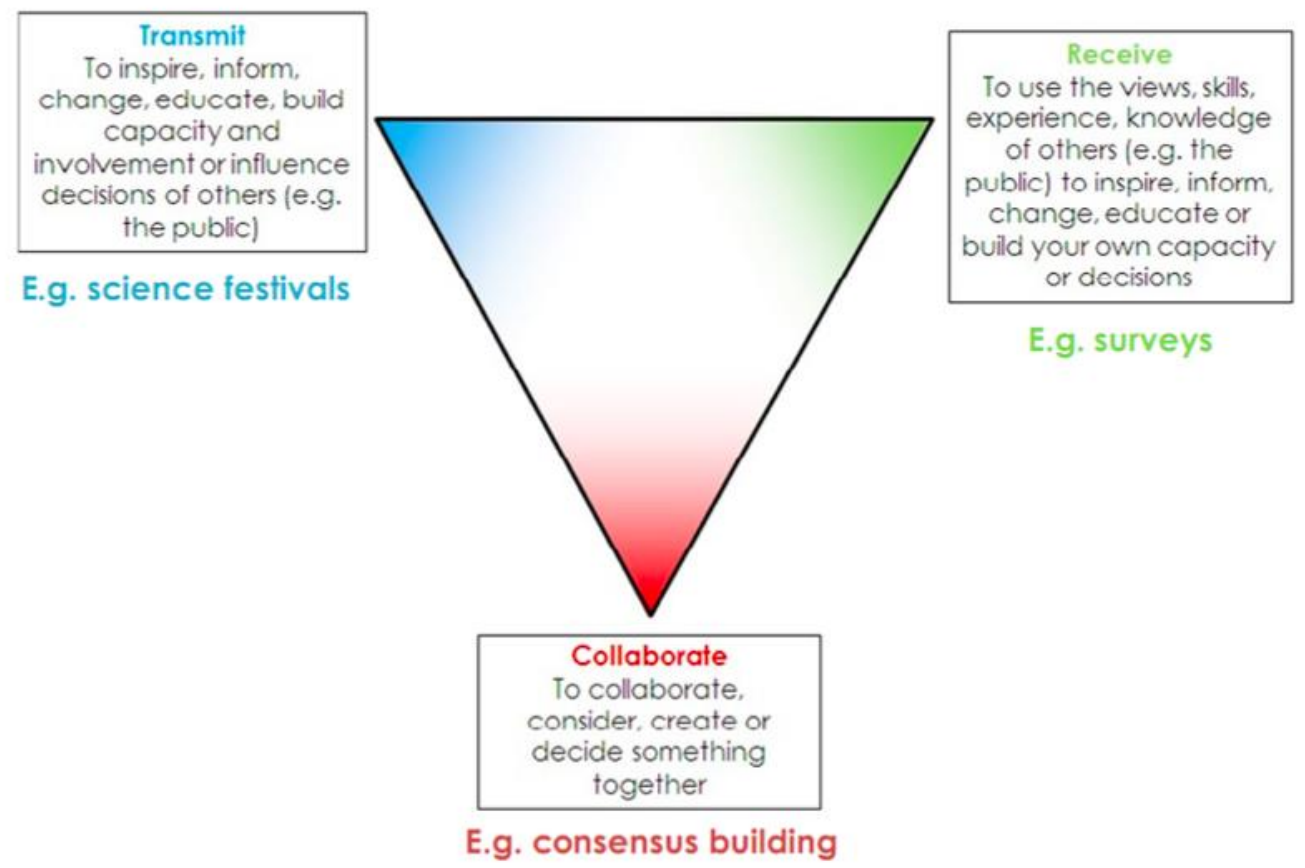

Public engagement policies in Science and Technology in theory can bring citizens more actively to the decision-making process on science issues. According to Fapesp Magazine ${ }^{3}$, for example, in Netherland, the REshape Innovation program from the University of Radboud aims to develop technologies and innovations to support patients, coordinated by Dr. Lucien Engelen. Engelen also founded the Patients Included project in 2012 to promote lay peoples' inclusion in medical and scientific debates. In addition, some scientific journals as British Medical Journal (BMJ) and Research Involvement and Engagement (RIE), published by BioMed Central (BMC), have invited patients and their relatives to participate in peer-review analyses about their own health problems. All papers are reviewed by specialists and patients for

\footnotetext{
${ }^{3}$ Available from: http://revistapesquisa.fapesp.br/2018/08/20/o-olhar-do-paciente/
} 
editorial decision and more than 700 people mainly without scientific background have contributed to these processes.

Public engagement also envisages bringing social frameworks to assess risks and benefits around specific technologies by stakeholders. These initiatives are often face-to-face and give everyone the opportunity to speak, to question and to be questioned by others, also with some influence on policy decisions. Through public dialogue, participants can potentially influence the resulting research (WILKINSON, 2012). Indeed, public engagement actions have been institutionally incorporated in many research institutions in Europe, especially in the United Kingdom. "Budget and human resources are devoted to these activities and researchers themselves are increasingly and institutionally encouraged to pursue this" third mission "alongside more traditional research and teaching duties" (BAUER \& JENSEN, 2011).

Policies for public engagement represent one way in which they are being include as mechanisms for accountability. Universities and research institutes receive extensive financial public investment are under increasing pressure to respond to external agendas and to "reinvent themselves" to meet the needs of society as a whole. "Public engagement demonstrates the availability of a university to listen and change.., [to] provide a safe space for dialogue and debate" (NCCPE, 2015). On the other hand, these initiatives can be seen to represent an initiative focused on marketing, branding or corporate social responsibility. In that sense, public engagement may represent a new strategy to strengthen and enrich the university's brand and identity, increasing public appreciation and support for higher education and research in order to negotiate the university's license to practice.

In Ibero-American countries, public engagement in science and technology may still be considered a pending cause, although in recent years Latin American, Spanish and Portuguese countries have increased their efforts to consolidate and expand their national science and technology systems. In this context, with limited resources and abundant needs, resources are likely to be more often allocated to grassroots actions such as strengthening research and capacity building and empowering scientists (CORTASSA, 2012).

In Brazil, science communication based on the deficit model has dominated public science and technology (S\&T), despite some public policies promoted by the 
former Ministry of Science, Technology and Innovation (MCTI) and other government agencies aligning more to public engagement in recent years (MASSARANI, 2012; CASTELFRANCHI, 2010). Therefore, the ways in which public engagement may become further embedded in such countries social and political contexts are still to be seen.

\section{Limits of public engagement in S \& T}

Expectations and proposals for public engagement can occur at various levels: (a) public policies for science, in terms of defining priorities for action and public investment; (b) social control over scientific practices, in terms of civil vigilance, accountability, social responsibility in public and private entities; and (c) public understanding of science and technology in cognitive and practical terms, but there can be significant variation in the feasibiliy of such approaches, dependent on a countries' existing capital.

First of all, in democratic regimes, public engagement is not so different from the formulation and construction of public policies more broadly, linked to political and strategic visions with a participatory bias which is as broad as possible. Secondly, it is expected that publics will, in some way, demand accountability and exercise oversight over scientific entities, as well as any other institution, guided by certain ethical standards and social responsibility. Thirdly, ways of cognitively sharing the making of science and its results come into play for many countries around the world as a part of wider efforts for scientific literacy, including for example in formal education.

In this way, forms of establishing engagement are also varied and offer opportunities to be combined: for example disseminate/inform and promote educational and awareness activities can work alongside promoting participatory forums with less or more influence in the decisions themselves, such as meetings, public consultations/hearings, committees and councils and with representation from civil society, government and scientific institutions.

However, this normative ideal of the public engagement in science and technology can also bring some questions. Firstly, the mere dissemination of scientific 
information is not enough for audiences to cognitively appropriate science and technology knowledge, especially in a more actively and critically way. In addition, social expectations and demands operate in a political, economic and cultural field of conflict which leads to difficulties in their assimilation, and innumerable dilemmas as to their applications. Different branches of science and technology affect the public in very different ways which, therefore, lead to some nuances around how different fields of science consider public engagement as well as the controversies they may potentially generate.

This leaves us with the following questions: What kind of participation and engagement can be achieved in science and technology? At what level? Who can participate? How are citizens chosen? What is the weight given to citizens and the scientists in the process? To which areas of science (basic science, applied sciences, humanities and social sciences) is it most relevant? What is the role of science and technology engagement in private and national strategy and investment (military investment, for example)? How can we think of a qualified debate about certain issues within a moving political landscape?

\section{Final thoughts}

Over the years, communicative practices with a dialogic, interactive and participatory focus have expanded around the world. Thinking about new communication models geared towards social dialogue and participatory democracy working for actions that enable public engagement can and should be the way forward for the public communication of science and technology and citizenship, despite many intrinsic limitations: "If we truly believe in democracy, then we must move towards public engagement models" (LEWINSTEIN, 2010, 62).

There is, however, a need to advance the investigation of the levels and possibilities of influence and participation of publics in science and technology given such limitations, and especially so, as pointed out by Bucchi (2008) when the social role of science is even further tested in the politics and democracy of contemporary times. Increasingly, science is politic-social and therefore cannot be thought of without a consideration of power and culture.

INTERIN, v. 24, n. 2, jul./dez. 2019. ISSN: 1980-5276. 
Finally, public engagement can lead to a questioning of science itself as a social institution with public communication and engagement continuing to play a role in how science itself is able to control its symbolic power. Public engagement in science and technology represents, in essence, political power and authority transfer, but in today's political context is it "... something that scientists or government agencies or industry leaders are willing to do?" (LEWINSTEIN, 2010, p. 27-28).

\section{REFERÊNCIAS}

BASTOS, A. Perspectivas do modelo relacional na comunicação de instituições de C\&T. Anais do XXXIX Congresso Brasileiro de Ciências da Comunicação (Intercom). São Paulo, 2016 .

BASTOS, A. Comunicação da Ciência para o Engajamento Público no Reino Unido. Anais do XXXIX Congresso Brasileiro de Ciências da Comunicação (Intercom). Rio de Janeiro, 2015.

BAUER, M.; JENSEN, P. The mobilization of scientists for public engagement. Public Understanding of Science. London, 2011.

BONNEY, R., BALLARD, H., JORDAN, R., MCCALLIE, E., PHILIPS, T., SHIRK, J., WILDERMAN ,C. Public Participation in Scientific Research: Defining the Field and Assessong its Potential for Informal Science Education: A CAISE Inquiry Group Report. Washington DC, 2009.

BORDIEU, P. Os usos sociais da ciência: por uma sociologia clínica do campo científico. São Paulo: Editora UNESP, 2004.

BUCCHI, M. Of deficits, deviations and dialogues: theories of public communication of science. In: Massimiano, B.; Trench, B. (Ed.). Handbook of public communication of science and technology. Routledge: London, 2008.

BUCCHI, M. Beyond Technocracy: Science, Politics and Citizens. SpringerVerlag: New York, 2009.

BULTITUDE, K. The Why and How of Science Communication. In: Rosulek, P., ed. Science Communication. Pilsen: European Commission, 2011.

CASTELFRANCHI, Y. Por que comunicar temas de ciência e tecnologia ao público? Muitas respostas óbvias... mais uma necessária. In: MASSARANI, L. (coord.). Jornalismo e ciência: uma perspectiva ibero-americana. Rio de Janeiro: Fiocruz / COC / Museu da Vida, 2010. 
CASTELFRANCHI, Y; FERNANDES, V. Teoria crítica da tecnologia e cidadania tecnocientíca: resistência, "insistência" e hacking. Revista Filos., Aurora, Curitiba, v. 27, n. 40, p. 167-196, 2015.

CORTASSA, C. La ciencia ante el público. 1a. ed. Buenos Aires: Eudeba, 2012.

DEWEY, J. En busca del público. In: DEWEY, J. La opinión pública y sus problemas. Madrid: Ediciones Morata, 2004.

EPSTEIN, S. Democracy, Expertise and AIDS Treatment Activism. In Kleinman, D. L. (ed) Science, Technology and Democracy. New York: SUNY,2000.

FOUCAULT, M. A ordem do discurso. São Paulo: Edições Loyola, 2007. Título original: L'ordre du discours. Leçon inaugurale au Collège de France prononcée le 2 decémbre 1970.

LEADBEATHER, C. We-Think: mass innovation, not mass production. London: Profile Books., 2008.

LEWEnsteIn, B. Models of Public Understanding: The Politics of Public Engagement. ArtefaCToS, vol. 3, n.o 1, 13-29, 2010.

MASSARANI, L. Comunicação da ciência e apropriação social da ciência: algumas reflexões sobre o caso do Brasil. Revista Uni-pluri/versidad, Vol. 12, N. ${ }^{\circ}$ 3, 2012.

MASSIMIANO, B.; Trench, B. Handbook of public communication of science and technology. Routledge: London, 2008.

NCCPE - National Co-ordinating Centre for Public Engagement. NCCPE Definition

Available from: http://www.publicengagement.ac.uk/explore-it/what-publicengagement.

SANTOS, B. (org.) Conhecimento prudente para uma vida decente: um discurso sobre as ciências revisitado. 2. Ed. São Paulo: Cortez, 2006.

SCIENCE FOR ALL. Public Engagement with Science and Society - a conversational tool. London: Department for Business, Innovation and Skills.2010. Available from: http://interactive.bis.gov.uk/scienceandsociety/site/all/2010/09/23/publicengagement-for-science-and-society-a-conversational-tool/.

RASK, M. et al. A Conceptual Model of Public Engagement in Dynamic and Responsible Governance of Research and Innovation - Innovative Public Engagement. 2016. 
WILKINSON, C. Community engagement and mobilisation: Critique of a public dialogue day. Project Report. Swindon, Swindon. 2012. Available from: http://eprints.uwe.ac.uk/18799

WILKINSON, C.; WEITKAMP, E. Creative Research Communication: Theory and Practice. Manchester University Press: Manchester, 2016.

Recebido em: 09.04.2019

Aceito em: 13.06.2019 